\title{
MORPHOLOGY, PRODUCTIVITY AND QUALITY OF GENJAH SUGAR PALM IN KUTAI NATIONAL PARK, EAST KALIMANTAN, INDONESIA
}

\author{
Liris Lis Komara $^{1 *}$, Nur Patria Kurniawan ${ }^{2}$ \\ ${ }^{1}$ Forestry Study Program, East Kutai Agriculture College School, Jl. Sukarno Hatta, East Kutai, \\ East Kalimantan 75611 \\ ${ }^{2}$ Kutai National Park, Jl. Awang Long No.33, North Bontang, Bontang city, East Kalimantan \\ 75311 \\ *Corresponding author: liskomara@yahoo.co.id
}

\begin{abstract}
Kutai National Park is the conservation forest in East Kalimantan, which can be used for community welfare through non-timber forest products utilization. One of the superior commoditty of non-timber forest products in Kandolo Village under the guidance of Kutai National Park is Genjah Sugar Palm (Arenga pinata Merr). This research objective was to determine the morphology, productivity and quality of the east kutai native genjah sugar palm. The materials used are fresh sap, the method of making palm sugar was by heating for 3 hours to evaporate the water. The heating is ended after it becomes thickened. After thickening, the stew is immediately removed from the heat. Before printing the thick sap is stirred so the heat is more evenly distributed. The result of research shows that the morphology of genjah sugar palm is very unique, because it has a short tree shape and a production age of 5-6 years. The productivity was quite high, the yield of sap is more than $12{\text { liters } \text { day }^{-1} \text {, the duration of tapping is }>3 \text { months tree }}^{-}$ ${ }^{1}$. The chemical compound quality of genjah palm sugar had water content, ash, sacrose, reducing sugar, copper and mercury content of $2.24 \%, 1.76 \%, 95.48 \%, 1.02 \%, 1.62 \mathrm{ppm}$ and $0.01 \mathrm{ppm}$.
\end{abstract}

Keywords: Kutai National Park, Genjah Palm Sugar, Sap

\section{INTRODUCTION}

Kutai National Park is a government institution that manages the National Parkin East Kalimantan. The management of the National Park area as a conservation forest can be used for community welfare, including the use of non-timber forest products. One of the non timber forest products that has become a leading commodity in the Kutai National Park and East Kutai Regency is the Arenga pinata (Tamsir, 2020).

Genjah Sugar palm can grow well in the Kutai National Park area with a distribution area from the Teluk Singkama Village to Teluk Pandan Village area (Tamsir, 
2020). This palm has its own characteristics, that become differentiates with another palm sugarin morphological form. The genjah sugar palm morphology was very different with the other sugar palm species in Indonesia (Tenda and Maskomo, 2012).

The genjah sugar palm morphology was very unique, that's because aresearch on the genjah sugar palm morphology soon became important to study about the physical form and body structure of Arenga pinata. Plant morphology is useful to identifying plants visually, thereby recognizing a very large diversity of plants. Morphology does not only describe the shape and structure of genjah sugar palm's body, but to determine the function of each part in plant life. Furthermore, trying to find out where the origin and structure of the body formed. In addition to the morphology, productivity of genjah palm sugar needs to be investigated. From this productivity, the results of palm sugar can be tested and confirmed to produce quality of genjah palm sugar. The purpose of this study was to determine the morphology and productivity of East Kutai native genjah sugar palm as a producer of quality sap and palm sugar.

\section{MATERIALS AND METHODS}

The research was conducted in theKutai National Park area, the research location in the Kandolo Village East Kutai Regency (Figure 1). The location chosen is an area that has genjah sugar palm population. The research location is at 100 meters above sea level altitude. Based on the Schmidt and Ferguson classification, Kutai National Park has a type $B$ climate with $Q$ values ranging from $14.3 \%$ - $33.3 \%$. Average annual rainfall of $1543.6 \mathrm{~mm}$ with 66.4 days of rainy days a year in average 5.5 days of months in average. The average temperature is $26^{\circ} \mathrm{C}$ (range 21 $34^{\circ} \mathrm{C}$ ) with $70 \%$ relative humidity. 


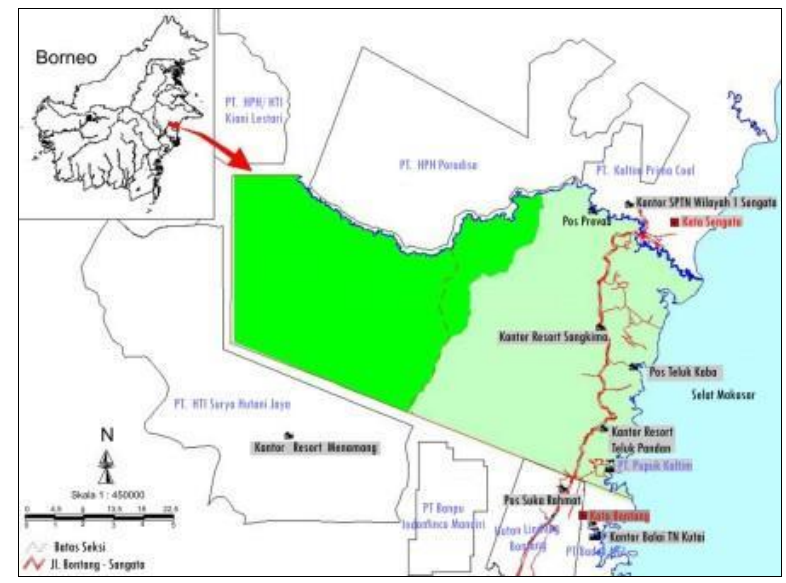

Figure 1. Map of research locations

The ingredients used are fresh sap cooked to printing the thick sap is stirred in order to evaporate the water. The method of making distribute the heat. Aren sucrose research was palm sugar was by heating the sap for 3 hours. carried out in several steps, namely hydolysis The heating is ended after it becomes conditions of sucrose determination, the thickened, with volume $8 \%$ from the initial analysis of reducing sugar samples using the volume. After thickening, the stew is Lane-Eynon method and the sucrose immediately removed from the heat. Before determination using $\mathrm{HCl}$ hydroluisa.

\section{RESULTS AND DISUSSIONS}

\section{Results}

Table 1 The Character diversity of Genjah Sugar palm from Kandolo village, Pandan Bay District and East Kutai Tall sugar palm at Paridan Village, Sangkulirang Sub District, East Kutai District.

\begin{tabular}{llcc} 
No & Characteristic & Genjah Sugar Palm & Tall Sugar Palm \\
\hline 1 & Height $(\mathrm{m})$ & $1.67 \pm 0.19$ & $10.68 \pm 2.63$ \\
2 & Girth $(\mathrm{cm})$ & $138.61 \pm 7.80$ & $155.50 \pm 2.96$ \\
3 & Number of green leafs & $24.36 \pm 4.22$ & $23.60 \pm 3.72$ \\
4 & Length of penduncle $(\mathrm{cm})$ & $181.12 \pm 29.92$ & $256.00 \pm 39.87$ \\
5 & Length of rachis $(\mathrm{cm})$ & $558.20 \pm 92.30$ & $646.00 \pm 89.20$ \\
6 & Length of Leaflet $(\mathrm{cm})$ & $115.40 \pm 12.50$ & $127.00 \pm 17.60$ \\
7 & Width of leaflet $(\mathrm{cm})$ & $5.98 \pm 0.63$ & $7.62 \pm 0.78$ \\
8 & Number of female inflorencense & $6.83 \pm 2.76$ & $6.75 \pm 1.23$ \\
9 & Number of male inflorence & $7.80 \pm 1.02$ & $8.50 \pm 1.60$ \\
10 & Girth of female penducle $(\mathrm{cm})$ & $36.04 \pm 8.20$ & $28.84 \pm 4.34$ \\
11 & Girth of male penducle $(\mathrm{cm})$ & $28.92 \pm 3.80$ & $28.95 \pm 5.08$ \\
12 & Length of female inflorencense $(\mathrm{cm})$ & $133.80 \pm 21.20$ & $192.73 \pm 39.33$
\end{tabular}


MORPHOLOGY, PRODUCTIVITY AND QUALITY OF GENJAH SUGAR PALM IN KUTAI NATIONAL PARK, EAST KALIMANTAN, INDONESIA

Table 1. Continued.

13 Length of male inflorence $(\mathrm{cm})$

$104.20 \pm 29.87$

$109.00 \pm 26.50$

14 Girth of female penducle $(\mathrm{cm})$

$172.90 \pm 11.30$

$192.00 \pm 41.26$

15 Girth of male penducle $(\mathrm{cm})$ $159.80 \pm 10.93$

$198.74 \pm 31.00$

Table 2. Sap production of 1-7 buches and tapping duration of Genjah sugar palm, at Kandolo village, Pandan Bay Sub District, East Kutai District.

\begin{tabular}{ccc}
\hline Male Flower Bunch & Sap Production/bunch (litre) & Duration of taping/bunch (day) \\
\hline 1 & 1389 & 96 \\
2 & 1397 & 82 \\
3 & 902 & 71 \\
4 & 687 & 65 \\
5 & 695 & 69 \\
6 & 688 & 67 \\
7 & 152 & 26 \\
Total & 5910 & 476 \\
\hline
\end{tabular}

Table 3. The fruit component character of Genjah sugar palm from Kandolo village, Pandan bay sub district

\begin{tabular}{llcc}
\hline No & \multicolumn{1}{c}{ Characteristics } & Genjah Sugar Palm & $\begin{array}{c}\text { Peridan Tall Sugar } \\
\text { Palm }\end{array}$ \\
\hline 1 & Weight of fruit $(\mathrm{g})$ & $26.15 \pm 2.71$ & $43.12 \pm 5.25$ \\
2 & Length of fruit $(\mathrm{cm})$ & $3.49 \pm 0.33$ & $4.55 \pm 0.44$ \\
3 & Width of fruit $(\mathrm{cm})$ & $3.66 \pm 0.34$ & $4.80 \pm 0.44$ \\
4 & Weight of Kemel $(\mathrm{g})$ & $1.09 \pm 0.34$ & $5.12 \pm 0.49$ \\
5 & Length of Kemel $(\mathrm{cm})$ & $2.00 \pm 0.33$ & $2.75 \pm 0.09$ \\
6 & Width of Kemel $(\mathrm{cm})$ & $1.50 \pm 0.33$ & $1.96 \pm 0.49$ \\
\hline
\end{tabular}




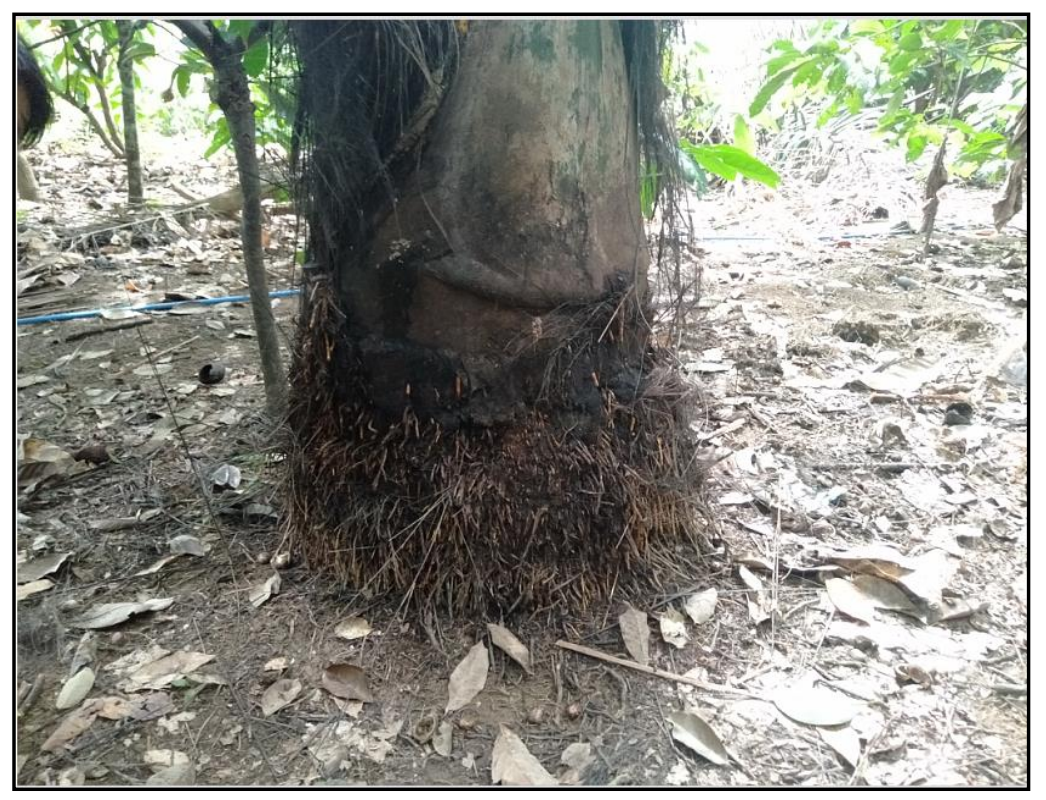

Figure 2. The characteristics of genjan sugar palm that are ready to be harvested, the charakteristics are the roots already visible

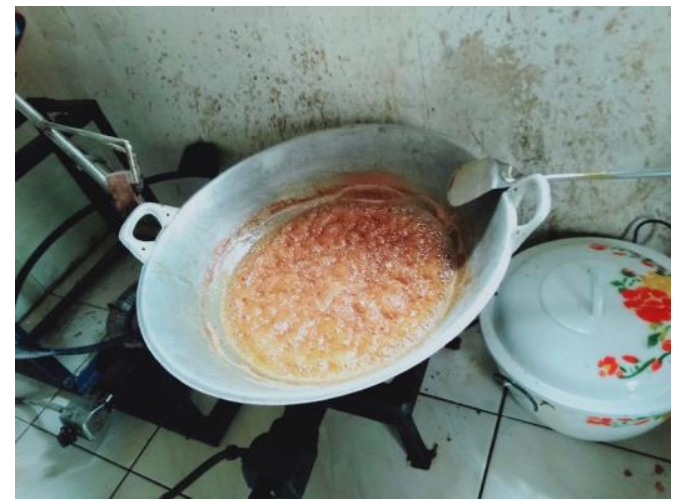

Figure 3. Sap Cooking Process

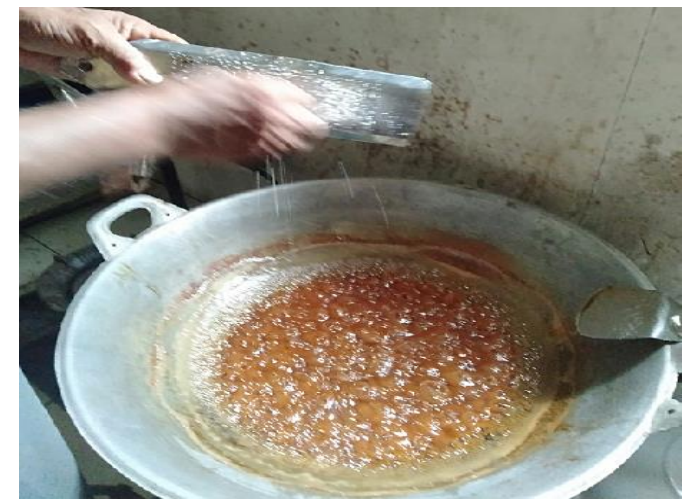

Figure 4. Cundlenut adding (ready to be printed) 
Table 3. Quality of printed sugar and palm sugar palm East Kutai, peridan palm sugar and the Indonesian National Standard.

\begin{tabular}{llllcccc} 
& \multirow{2}{*}{ Test Results } & \multicolumn{2}{c}{$\begin{array}{c}\text { Genjah Palm } \\
\text { Sugar }\end{array}$} & \multicolumn{2}{c}{$\begin{array}{c}\text { Peridan Palm } \\
\text { Sugar }\end{array}$} & \multicolumn{2}{c}{$\begin{array}{c}\text { Indonesian National } \\
\text { Standard }\end{array}$} \\
\cline { 3 - 8 } & & $\begin{array}{c}\text { Printed } \\
\text { sugar }\end{array}$ & $\begin{array}{c}\text { Palm } \\
\text { sugar }\end{array}$ & $\begin{array}{c}\text { Printed } \\
\text { sugar }\end{array}$ & $\begin{array}{c}\text { Palm } \\
\text { sugar }\end{array}$ & $\begin{array}{c}\text { Printed } \\
\text { sugar }\end{array}$ & $\begin{array}{c}\text { Palm } \\
\text { sugar }\end{array}$ \\
\hline 1 & Water (\%) & 2.24 & 1.66 & 2.2 & 1.67 & 2.0 max & 2.0 max \\
2 & Ash (\%) & 1.76 & 2.14 & 1.1 & 1.78 & 2.0 max & 2.0 max \\
3 & Sakrose (\%) & 95.48 & 93.14 & 94,1 & 90,3 & 77 min & 90 min \\
4 & Reduction sugar & 1.02 & 1.16 & 1.31 & 1.45 & 10 max & 6.0 max \\
& $(\%)$ & & & & & & \\
5 & Lead (ppm) & Ttd & Ttd & Ttd & Ttd & 2.0 max & 2.0 max \\
6 & Cover (ppm) & 1.62 & 2.08 & 1.77 & 2.18 & 10 max & 10 max \\
7 & Mercury (ppm) & 0.01 & 0.01 & 0.01 & 0.01 & 1.0 max & 1.0 max \\
\hline
\end{tabular}

Ket: Peridan palm sugar data taken from Komara (2018)

\section{Discussions}

\section{Genjah Sugar Palm Morphology}

The morphology of east kutai genjah sugar palm Observations, precisely in the village of Kandolo and the species of tall sugar palm of the Peridan village Sangkulirang subdistrict. The results of the morphological characters of east kutai genjah sugar palm observations in Kandolo Village, Teluk Pandan District, East Kutai Regency are presented in Table 1.

The morphology of genjah sugar very differet from a ordinary sugar (exp from peridan, sangkulirang subdistrict), where the height of genjar aren almost $84.36 \%$, the girth almost $10,86 \%$ different, length of penduncle $29.25 \%$ different, length of rachis $13.59 \%$ different. But for the number of leaf $3,2 \%$ and number of female inflorence $1.19 \%$ much higher from ordinary sugar palm. And the girth of male penducle is almost the same. Width of leaflet $21.52 \%$ different, number of male inflorence $8.24 \%$ different and girth of male penducle is $19.58 \%$ different.

Tenda and Maskmoro (2012) research found that there are low variousity of the vegetative characters, while some of the generative characters had high coebisien variousity in the stem height, stem girth, number of green leaves, length of peduncle, length of rachis, length of leaflets and width of leaflets. Leaves play a role in the process of photosynthesis to produce carbohydrates that needed by Aren plants. The process of photosynthesis plays a role in sugar palm in producing sap. Based on the characters of the number of green leaves, the length of the rachis, the length of the leaflets and the width 
of the leaflets, the sap produced in the same plant did not vary (Tenda et al., 2012). While Tenda and Maskmoro (2012) research found that there are a small coefisient variousity in generative characters in the number of inflorence, girth of female peduncle, the girth of male peduncle, the length of female peduncle and the length of male peduncle, it means the selection cannot be made on these characters because they will not progress to improve their traits.

Tenda and Maskmoro (2012) research found that there are a high variousity in the number of female inflorencense, the girth of female penducle and the length of male inflorence, that mean the selection to improve the genjah sugar palm will be directed at these characters. Genetic variousity is needed to determine the amount of genetic variation that exists. The large genetic variousity reflects the genetic resources needed for ecological adaptation in the short term and evolution in the long term. According to Rimbawanto and Widyatmoko (2006), to be able to adapt to environmental changes, a plant must have a genetic diversity base with a cooficient variousity $>20 \%$.

The Girth of male peduncle and length of male inflorence, affect the amount of sap produced and the duration of tapping. The bigger the stems and the longer the male inflorence, the more sap is produced and the longer the tapping will take. Genjah sugar palm is located in Teluk Pandan District are realy different from sugar palm in Peridan, Sangkulirang District. The start production age of both sufar palm is very different, genjah palm sugar began tapping at 5-6 years old while he peridan, Sangkulirang sugar palm began to be tapped at 10-12 years old.

A genjah sugar palm tree has 8 males of inflorence average. Generally, the tapping is only up to the 7 th inflorence and the average time spent for tapping each plant is 2.25 months. The results of observations from the production of per inflorence sap and tapping time for per inflorence (inflorence 1-7) showed that the sap production and tapping time began to decline after the 3rd inflorence. The production of the $1 \mathrm{st}$ and 2 nd palm sap production was 1,389 liters and 1,397 liters respectively, but in the 4th plant the sap production decreased to 687 liters. Mayang 7th production of palm sap quickly only 152 liters as seen in table 2 .

Acording to Gunawan et al. (2018) The main products of genjah sugar palm are sap, flour and palm fiber, the sap is a product of Aren plants that can be processed into printed sugar, palm sugar, palm wine, alkocol and 
others. The interview results show that the average sap production per day in 2020 is 12 5 liters with $12.25 \%$ sugar content and an 88 days average tapping period, this result is higher than genjah palm sugar in Sumatra which only produces $4-10$ liters per inflorence perday with tapping time of about 3 months (Novarianto et al., 1994).

The fruit component character of Genjah sugar palm from Kandolo village, Pandan bay sub district were quite different, its about $39.36 \%$ different in weight of fruit, $23.30 \%$ in length of fruit, $23.75 \%$ in width of fruit, $79,71 \%$ in weight of kemel, $27.27 \%$ in length of kemel and $23,47 \%$ in width of kemel (Table 3).

An old genjah sugar palm fruit which generally have greenish yellow to yellow and the shape of the fruit is slightly rounded. The results of the genjah sugar palm fruit component analysis showed that all the characters observed had low variousity, except for seed weight (Tenda and Maskmoro 2012). Palm fruit components are very different from Genjah sugar palm, especially in the character of fruit weight and seed weight. An old genjah sugar palm seed are generally slightly round in shape, brownish black, shiny, smooth and triangular in shape. Genjah sugar palm has has six female branches and each inflorence has 840 seeds, each of which consists of 280 fruits, each consisting of three seeds and $80 \%$ of the potential to become seeds. Meanwhile, according to Maliangkay (2007), one productive palm tree produces 90,000 seeds consisting of 5000 fruits per inflorence and 3 seeds per ftuits, on one tree there are 4-7 female inflorence (on average 6 female inflorence).

\section{East Kutai Genjah Sugar Palm Production}

The East Kutai genjah palm sugar commodity has long been cultivated and processed by the Nyiur Melambai Group that processing palm sugar in Kandolo Village. The Palm Sugar Farmer Group of Nyiur Melambai is group that has been fostered by the Kutai National Park since 2016. This group was chosen because it has the potential to be developed, that is genjah sugar palm which become the characteristic of the East Kutai region. East kutai genjah sugar palm became the first sugar palm variety to become a National Superior Variety through the Minister of Agriculture Decree number: 3879 / Kpts / SR.120 / 9/2011 dated 14 September 2011 (Tamsir, 2020)

The production of palm sugar in East Kutai is carried out by the Palm sugar farmer groups. Observations and research on sugar production are carried out to support the production of quality palm sugar. The 
production of palm sap from trees after tapping is generally made directly into sugar, both printed sugar and palm sugar. The sap is taken from trees that have been sufficiently harvested with one of the characteristics, the roots of the palm sugar plant are already visible (Figure 2).

In palm sugar processing, because of the fermentation process by the Saccromyces sp bacteria. The harvested sap becomes acidic. At least 90 minutes after being harvested from the sap place, it must be processed immediately. The sap is poured while filtered with wire mesh made of copper and then poured into the furnace to be immediately heated (boiled). Heating lasts for 1-3 hours, depending on the amount (volume) of sap available. Heating the stove while stirring the boiling sap, the froth that appears on the surface of the sap must be removed, so that the palm sugar is not too dark (black), dry and the results last long. The heating is ended after the sap becomes thick with a volume of about $8 \%$ of the initial volume before heating. The heat of the fire should exceed $100^{\circ} \mathrm{C}$, or at high heat, otherwise the processed sap will not turn into sugar.

If the sap that is heated feels heavy when stirred and became thickens, it is best to use silk to prevent too much sugar from drying on the edges of the container. After it really thickens, then the stew is immediately removed from the heat (The process of making palm sugar can be seen in Figure 3). Then the sap stew is given candlenut (Figure 4). Before printing, stir the thick sap to heat it evenly. Stirring should not be too long to prevent the formation of sugar crystals that make printing process difficult.

The failure of making genjah palm sugar is caused by two things, they are temperature and raw materials. Very high temperatures exceed $120^{\circ} \mathrm{C}$ which causes the sugar to burn or burn until it turns dark to black with an abnormal odor (caramelflavored smell). In addition, it can also be caused by the high reducing content in sugar which will cause the sugar to be more hygroscopic and quickly burn (caramelize). Another failure is because the raw material (sap) is already acidic so that the sugar formed does not become solid when heated (Baharudin and Taskirawati, 2009). Palm sugar production has two forms, namely printed sugar and palm sugar. The production of palm sugar, the thick sap is continuously cooked, stirred until dry, into separate grains (Figure 5). If the water content is still high, the dried sap is put in the oven (Figure 6). 


\section{Quality of East Kutai Genjah Palm Sugar}

The results of the 2020 interview found that every genjah palm sugar farmer processes 50 liters of sap per day in average and can produce about $6 \mathrm{~kg}$ of palm sugar or 12 pieces of printed sugar. The size of sugar weighs $0.5 \mathrm{~kg}$ per grain with a printed sugar price of Rp. 15,000 per grain and palm sugar of Rp. 100,000 kg-1. In general, genjah palm sugar farmers process half of the palm sugar and the other half is printed sugar. Palm sugar farmer gross income ranges from Rp. 180,000Rp. 390,000 day ${ }^{-1}$. The quality of palm sugar produced after analyzing both printed sugar and palm sugar both have good quality, that is as the requirement the Indonesian National Standar SNI 01-3743-1995 (Table 3). Palm sugar production of good quality, which needs to be improved is the marketing so that it can be sell online. In Table 3, we can see the comparison of the quality of printed sugar and palm sugar from East Kutai genjah palm sugar in Kandolo Village, Teluk Pandan District and sugar palm from Peridan village, Sangkulirang.

The water content between genjah palm and ordinary palm sugar in printed sugar its higher $1.8 \%$ and in the palm sugar is $0.6 \%$ much lower. The water content $\max$ is 2 , its realy important to know because the higer water content the more risk for the sugar to get a fungy on it (Susi, 2012). Ash as content is higher $20-60 \%$, the ash show how much organic matter and non organic matter in the sugar (Komara, 2018). The reduction sugar is lower $20-22.14 \%$ from the ordinary sugar. There is no lead detected, the cover content is lower $4.59-8.48 \%$ than the ordinary sugar and there is no different in mercury content, its good according to the Indonesia national standard.

Home business for palm sugar products soon has good economic prospects for the community. If this genjah sugar palm cultivated in a better way, with a plant population of 160 plants per hectare, then the genjah sugar palm will soon start producing at 5-6 years old. The calculation 160 genjah sugar palm plants tapped for 90 inflorence with 12 liters of sap production day ${ }^{-1}$. Total daily sap production will gots 1080 liters of sap (Tenda et al., 2011).

According to Tamsir (2020), sugar palm commodity can be used as an intercropping and reforestation plant. Aren serves as a plant for land conservation without causing competition with other food crops. Especially for genjah sugar, this species has more advantages than the other sugar palm. Some of the potential of genjah sugar palm are having a relatively faster production age of around 5-6 years, while other palm sugar 
species are only producing at the 10 years old. The sugar content is higher or above standard. The height from the ground is about 2.5 meters, while other species are about 8 meters. The fruit is thicker so that it has the potential to be a source of planting material on a large scale. It is estimated that 1 inflorence can become planting material for 12 hectares. Genjah sugar palm is relatively more resistant to pests and diseases. Genjah sugar palm has a high economic value benefits because each plant can produce sap of more than 12 liters day $^{-1}$ with tapping time of more than 2 months tree $^{-1}$. The most valuable part of the high economic value of sap is used as raw material for the production of printed sugar or palm sugar

The Nyiur Melambai palm sugar pocessing farmer group has already depelops palm sugar products in many creations such as brown sugar in powder form or what is commonly referred to as palm sugar in $500 \mathrm{~g}$ per packs, Palm sugar brown ginger 500 g per packs and brown sugar plus pasak bumi (Eurycoma longifolia) 500 g per packs. Their products already widely known in East Kutai and its surroundings. Some of its products have even been included in various promotional events in regional and national scale.
The Kutai National Park is the companion of the Nyiur Melambai farmer group, they continued to provide support in many forms such as building for producing and meeting of the group member, provides a seed and teach how to plant the genjah sugar palm, teach them how to manage their production finance budget, providing production equipment and product packaging equipment. The varieties of genjah sugar palm have become a matter of pride because they are important varieties and a superior commodity. The promotion of local varieties of east kutai genjah sugar palm, should be accompanied by the promotion of the welfare of cultivated farmers and processing groups of palm sugar.

\section{CONCLUSIONS}

The East Kutai genjah sugar palm, as one of the non-timber forest products has been cultivated for a long time in the area of East Kutai Regency, precisely in the forest area of the Kutai National Park. The spread of gemjah sugar palm is very wide in the area of Teluk Pandan sub-district, so its ownership needs to be protected as one of the unique biological wealth of East Kutai. The morphology of early palm sugar is very unique, different from other palms in general because it has a short tree 
shape and a production age of around 5-6 years. The productivity of early palm sugar is quite high, the yield of sap is> 12 liters / day, and the duration of tapping is $>2.5$ months / bird. The quality of early palm sugar is very good, namely having water content of $2.24 \%$, ash $1.76 \%$, sacrose $95.48 \%$, reducing sugar $1.02 \%$, copper $1.62 \mathrm{ppm}$ and mercury 0.01 ppm.

\section{ACKNOWLEDGEMENT}

The author would like to express deep gratitude to the Kutai National Park for assisting accommodation, transportation and discussion during the research. Thank are also conveyed to Ibu Hadrah from the Nyiur Melambai Farmer Group in Kandolo Village Teluk Pandan district and farmer group from Sangkulirang who helped in providing the location and research materials. Thanks to the Genjah Sugar Palm Team of East Kutai Agriculture School for the team work, so this research can run smoothly according to the planned schedule.

\section{REFERENCES}

Anonymous, Attachment to the Regulation of the Minister of Agriculture of the Republic of Indonesia Number 133 / Permentan / OT.140 / 12/2013 concerning Guidelines for good Arenga pinnata MERR cultivation.

Gunawan, R., U. G. Ramadhan, J. Iskandar, and R. Partasasmita. (2018). Local knowledge of utilization and management of sugar palm (Arenga pinnata) among Cipanggulaan People of Karyamukti, Cianjur (West Java, Indonesia). Biodiversitas, 19(1): 93105.

Komara, L. L. (2018). The Efects of Candlenut as Mixed Ingredients on the Palm Sugar Quality in the Penyolongan Village of Sangkulirang Districts East Kutai. The $1^{\text {st }}$ International Symposium on Tropical Forestry and Environmental Sciences (ISTFES 2018).

Maliangkay, R. B. (2007). Cultivation techniques and rehabitation of palm plants. Bulletin Palma No. 33.

Novarianto, H., H. G. Lengkey, and E. T. Tenda. (1994). Characteristics and similarities of Aren populations from the provinces of Bengkulu, West Sumatra and North Sumatra. Coconut Research Journal 7 (2): 1-7.

Susi. (2013). Effects of Palm Sugar Variety to Quality of Crystal Palm Sugar Produced by Small Agroindustry. Ziraa'ah, 36(1):1412-1468.

Tamsir, S. (2020). Management of Conservation Areas through Commodities Quickly East Kutai Aren. Earth peg bulletin. Issue 1.

Tenda, E. T., and I. Maskromo. 2012. Morphological Characteristics and Potential of Fast Palm Aren Production in Kutim. The Palma Bulletin, Vol 13 No.2.

Tenda, E.T., D. S. Pandin, and I. Maskromo. (2012). The Potential of Rapid Aren Development - Plantation Research Center.litbang.pertanian.go.id 